\title{
Gerakan sosial Budha Tzu Chi pasca reformasi di Kota Medan
}

\section{Post-reformation Budha Tzu Chi social movement in Medan}

\author{
Rholand Muary, Pujiati, Rizabuana Ismail \\ Program Studi Magister Sosiologi Fakultas Ilmu Sosial dan Ilmu Politik \\ Universitas Sumatera Utara \\ Jalan Dr A. Sofian No. 1A Kampus USU Medan, Sumatera Utara \\ E-mail: rholandmuary@gmail.com
}

\begin{abstract}
This study discusses the social movement conducted by post-reform Tzu Chi organization in Medan. The theory used is theory of social movements with three main factors in social movements; 1) political opportunity structure, 2) collective action frames, and 3) resource mobilization theory. This study aims to a) looking the concept of social movements, b) analyzing the concept of religious movements and c) revealing the position of Tzu Chi in Buddhism. This research applies qualitative methods with direct observation by analyzing subjective and objective experiences in sociological approach. This study was conducted in Medan City due to the following reasons: (1) the diverse population of Medan (2) Tzu Chi has many programs and volunteers in this city. The key informant in this study is the management of structural organization Tzu Chi, as it is considered representative and experienced in the organization. Additional informants are regular volunteers. The results of this study reveals that in the post reform era, Tzu Chi was growing and getting support from the inter-faith and ethnic. Majority ethnic of Tzu Chi is Chinese and form an organization which plays role as a container in showing its identity to maintain social stability and harmony amidst the diverse city of Medan. Their funding network collected through the business network, kinship and spiritual motivation of Buddhist teachings make organizational resources increasingly move to broaden the vision and mission of the organization. In conclusion, in the socio-religious context, Tzu Chi purifications for its Buddhist followers and implements organizational management patterns with 4 in 1 systems which considered modern, minimizing organizational conflicts and able to face the challenges.
\end{abstract}

Keywords: social movement, political opportunity structure, collective action frames, resource mobilization, movement of purification

\begin{abstract}
Abstrak
Penelitian ini membahas tentang gerakan sosial yang dilakukan oleh organisasi Tzu Chi pasca reformasi di Kota Medan. Menggunakan teori gerakan sosial dengan tiga faktor utama pada gerakan sosial yakni 1) struktur kesempatan politik, 2) pembingkaian aksi kolektif serta 3) teori mobilisasi sumber daya. Penelitian ini bertujuan, a) melihat konsepsi gerakan sosial, b) gerakan keagamaan dan c) mengungkapkan kedudukan Tzu Chi pada agama Budha. Menggunakan metode penelitian kualitatif, menganalisis setiap pengalaman subjektif dan objektif dalam pendekatan sosiologis. Penelitan ini dilakukan di Medan. Penelitian ini dilakukan di Kota Medan sebab penduduk Kota Medan yang beragam dan Tzu Chi punya banyak program dan relawan di kota ini. Informan kunci pada penelitian ini, yaitu pengurus struktural organisasi Tzu Chi, yang dianggap representatif dan memiliki pengalaman dalam organisasi, sementara informan tambahan adalah para relawan biasa. Hasil penelitian ini mengungkapkan bahwa pasca reformasi, telah membuka kesempatan untuk Tzu Chi melakukan gerakan sosial yang berkembang dan mendapatkan dukungan yang berasal dari lintas agama dan etnis. Tzu Chi yang diisi oleh mayoritas etnis Tionghoa menjadikan organisasi ini sebagai wadah dalam menunjukkan identitasnya untuk menjaga stabilitas dan keharmonisan sosial di tengah masyarakat kota Medan yang beragam. Jaringan pendanaan mereka yang dihimpun melalui jaringan bisnis, kekerabatan serta motivasi spiritual ajaran Budha membuat sumber daya organisasi kian bergerak untuk memperluas visi dan misi organisasi. Dapat disimpulkan bahwa dalam konteks sosial keagamaan, Tzu Chi melakukan gerakan purifikasi (pemurnian) bagi pengikutnya yang beragama Budha dan menerapkan pola manajemen organisasi dengan sistem 4 in 1 yang dianggap modern, meminimalisir konflik organisasi serta mampu menghadapi tantangan zaman.
\end{abstract}

Kata kunci: gerakan sosial, struktur kesempatan politik, pembingkaian aksi kolektif, mobilisasi sumber daya, gerakan purifikasi 


\section{Pendahuluan}

Gerakan sosial yang dimulai pada era 1970-an dan setelahnya, merupakan periode dekonstruksi yang menyoroti fenomena gerakan sosial terkait dengan struktur-struktur individual dan sosial yang tidak selalu memiliki unsur-unsur baku seperti gerakan fundamentalis berbasis agama yang terjadi di dunia sekarang seperti gerakan Islamic State (IS) di Iraq dan Suriah, gerakan kanan baru, politik identitas, politik rasial, dan sebagainya. Para sosiolog gerakan sosial menanggapi kenyataan baru itu dengan teori dan konsep kebudayaan, pembingkaian dan konstruksi identitas (Mirsel 2004).

Budha Tzu Chi sebagai organisasi sosial tidak bisa dilepaskan dari konteks struktur makro baik sosial, ekonomi, maupun politik. Apa yang mereka lakukan sebenarnya berangkat dari konteks persoalan kemiskinan struktural dan kebijakan negara. Karena itu, aksi mereka dalam studi ini dilihat sebagai aksi dari aktor sosial dalam konteks struktur sosial yang lebih luas. Untuk memahami hal tersebut konseptualisasi teori gerakan sosial dapat membantu melihat apa yang mereka lakukan dalam konteks struktural. Gerakan sosial dalam konteks ini mendekati konsep gerakan sosial baru (new social movement).

Gerakan sosial baru merujuk pada suatu konsepsi yang membedakannya dengan konsep gerakan sosial yang lama dimana gerakan sosial lama cenderung politis, melibatkan aksi massa serta berorientasi kelas. Gerakan sosial baru cenderung dipahami sebagai gerakan yang kultural, tidak melibatkan aksi massa, lebih dekat dengan isu sehari-hari, dalam hal ini adalah kesempatan memberikan manfaat kemanusiaan melalui misi-misi Tzu Chi itu sendiri.

Tzu Chi sendiri dapat dikategorikan sebagai civil society dan gerakan sosial. Civil society sebagai aktor dipahami dari dua perspektif. Perspektif pertama memahami civil society sebagai ruang sosial (civic sphere) di luar negara dan pasar tempat anggota-anggota masyarakat melakukan aktualisasi diri untuk kepentingan anggota-anggota masyarakatnya. Penekanan pada posisi di luar negara dan pasar di sini terlihat ingin menunjukkan kemandirian aktifitas kolektif masyarakat tersebut dari pengaruh dan kepentingan kekuasaan politik serta kepentingan pemodal besar (Hikam 1996).

Perspektif kedua melihat civil society sebagai aktor sosial di dalam ruang civil society tersebut yang relatif terorganisasi dan mandiri dari pengaruh negara dan pasar yang bekerja untuk kepentingan masyarakat luas atau kelompok-kelompok dalam masyarakat (public goods). Mereka dicirikan sebagai kelompok yang mandiri, voluntaristik, dan tidak berorientasi profit (Morris 2000).

Organisasi Tzu Chi secara harfiah dimaknai “Memberi dengan cinta kasih". Pendiri Tzu Chi, Master Cheng Yen yang memiliki nama asli Wang Chin-Yun dilahirkan pada tanggal 14 Mei 1937 di Chingsui, Taiwan bagian tengah. Dalam sejarah singkatnya dalam mendirikan Tzu Chi ini yakni peristiwa saat dimana Master Cheng Yen bersama beberapa pengikutnya datang ke suatu balai pengobatan di Fenglin untuk mengunjungi salah seorang umat yang menjalani operasi akibat pendarahan lambung. Ketika keluar dari kamar pasien, dirinya melihat bercak darah di atas lantai tetapi tidak tampak adanya pasien.

Dari informasi yang didapat, diketahui bahwa darah tersebut milik seorang wanita penduduk asli asal Gunung Fengbin yang mengalami keguguran. Karena tidak mampu membayar NT\$ 8.000 (sekitar Rp 2,4 juta), wanita tersebut tidak bisa berobat dan terpaksa harus dibawa pulang. Saat yang bersamaan juga ada tiga orang suster Katolik dari Sekolah Menengah Hualien datang berkunjung untuk menemui Master Cheng Yen. Kemudian salah seorang suster katolik itu bertanya kepada master, "Agama Katolik kami telah membangun rumah sakit, mendirikan sekolah, dan mengelola panti jompo untuk membagi kasih sayang kepada semua umat manusia, walaupun Budha juga menyebut menolong dunia dengan welas asih, tetapi mohon tanya, agama Budha mempersembahkan apa untuk masyarakat?" Kata-kata ini sangat menyentuh hati Master Cheng Yen. 
Maka dari itu Master Chen Yen pun merumuskan misi organisasi Tzu Chi, antara lain: 1) misi amal, 2) misi kesehatan, 3) misi pendidikan, 4) misi budaya humanis, 5) pelestarian lingkungan. Cheng Yen ditunjuk sebagai "Master" oleh semua pengikutnya dan menghormati secara penuh sebagai tokoh agama dan memimpin organisasi. Pengalaman hidupnya ini menjadi inspirasi dan membentuk Budhisme baru. Kini Tzu Chi menjadi organisasi kemanusiaan yang berkembang di 52 negera dan menjadi penanda kebangkitan agama Budha (Tzu Chi 2013). Budha sebagai seperangkat nilai dan ajaran spiritual keagamaan, dalam pendekatan teori fungsional menurut O'Dea (1996) menjelaskan bahwa agama mempunyai fungsi di masyarakat. Istilah fungsi ini menunjukkan sumbangan yang diberikan pada agama, atau lembaga sosial lain untuk mempertahankan keutuhan masyarakat sebagai usaha-usaha aktif dan berjalan secara terus menerus. Dengan demikian peranan yang dilakukan agama dalam rangka mempertahankan kelangsungan hidup masyarakat menjadi hal yang utama. Selain itu, terdapat dua pendapat yang melihat peran agama dalam proses perubahan sosial. Pertama, memandang agama dimaknai sebagai institusi yang menghambat proses perubahan sosial. Pada posisi ini agama diartikan sebagai kekuatan konservatif karena tidak dapat mendukung perubahan sosial dan cenderung mempertahankan status quo yang kedua, memandang agama sebagai unsur penting yang turut mempercepat perubahan sosial.

Agama dalam istilah konservatif dimaknai sebagai nilai-nilai, kepercayaan dan kebiasaan yang sifatnya tradisional dan dapat berubah menjadi kelompok yang fundamentalis yang sifatnya kaku dalam memaknai perubahan sosial. Fundamentalisme ini sering disamakan dengan kelompok ekstrimisme, fanatisme politik, terorisme dan anti Amerika, sedangkan kelompok fungsionalis berpegang bahwa masyarakat harus berada pada posisi yang stabil, seimbang, terintegritas dan agama dalam hal ini berfungsi untuk mempertahankan stabilitas sosial, keseimbangan antar unsur masyarakat, solidaritas dan integrasi sosial. agama berfungsi membantu mempertahankan eksistensi kelangsungan hidup masyarakat (Scharf 2004).

Tan (2008) meneliti tentang popularitas dan daya tarik Tzu Chi untuk memperhitungkan pertumbuhannya di Singapura. Dalam penelitian tersebut, keberhasilan Tzu Chi berkembang di Singapura karena Tzu Chi memiliki ciri khas, yakni menarik relawan yang berasal dari multi agama, dan multi etnisitas. Misalnya seorang Hindu dapat terus menyembah dewa, seorang Katolik bisa pergi ke gereja, tetapi keduanya dapat diterima dalam Tzu Chi sebagai anggota non Budha. Hal ini menimbulkan berbagai latar belakang keanggotaan Tzu Chi dan menjangkau basis yang luas dari keanggotaan melalui struktur yang mapan dan menyediakan berbagai layanan dan kegiatan untuk non anggota untuk berinteraksi dan belajar tentang Tzu Chi. Dengan strategi rekrutmen yang efektif dan proses sosial untuk mempertahankan anggota baru ke dalam kelompok, Tzu Chi menekankan pada tindakan berorientasi pendekatan pemahaman agama. Karena anggota menikmati kebebasan untuk memilih, hal ini membantu mengatasi hambatan agama bagi anggota yang berbagi pandangan dunia yang berbeda dari Budhisme. Penelitian ini bertujuan untuk menganalisis konsep gerakan sosial dan gerakan keagamaan yang dibangun oleh organisasi Tzu Chi di kota Medan dan melihat kedudukan organisasi ini pada Agama Budha itu sendiri.

\section{Metode Penelitian}

Penelitian ini menggunakan pendekatan sosiologi agama dengan metode penelitian kualitatif. Di mana memfokuskan pada: pertama, kelompok-kelompok atau lembaga sosial keagamaan yang meliputi pembentukannya, kegiatan demi kelangsungan hidupnya, pemeliharaan dan pembubarannya. Kedua, perilaku individu dalam kelompok tersebut (proses sosial yang mempengaruhi status keagamaan dan perilaku ritual (Robert 1984:3). Informan dalam penelitian ini sebanyak 15 orang, 6 di antaranya merupakan informan kunci dan 9 adalah informan tambahan. Informan kunci dalam penelitian ini ialah orang-orang yang menduduki jabatan strategis dan fungsional dalam organisasi Tzu Chi, sedangkan informan tambahan adalah para relawan yang biasa ikut dalam kegiatan Tzu Chi. Lokasi penelitian ini berada di Medan yakni di kantor Tzu Chi Kota Medan di Komplek Cemara Asri Jalan Boulevard Blok G/1 No 1-3 dan di Komplek Jati Junction Blok P No. 1 Jalan Perintis Kemerdekaan. Lokasi penelitian juga dilakukan di luar kantor atau tempat-tempat yang lain untuk mendukung tujuan penelitian. 


\section{Hasil Penelitian dan Pembahasan}

\section{Gerakan sosial Budha Tzu Chi}

Gerakan sosial atau social movements telah menjadi sebuah studi dari berbagai penelitian. Perkembangannya yang begitu cepat, terutama setelah mulai bermunculannya berbagai gerakan pada tahun 1960-an yang mengusung berbagai tujuan, menjadikan topik ini cukup menarik perhatian (Porta \& Diani 2006). Hal ini mengakibatkan hadirnya beragam perspektif yang berkembang dalam melihat kemunculan sebuah gerakan sosial. Dalam satu dekade terakhir ini, perspektif gerakan sosial didominasi oleh pendekatan political approach. Pendekatan ini melihat gerakan sosial dalam kerangka state-centerdness, menjadikan negara sebagai target dari gerakan sosial, karena negara adalah satu-satunya otoritas (source of power) (Armstrong \& Bernstern 2006). Pandangan ini mendapatkan banyak kritikan, terutama sejak mulai berkembangnya apa yang disebut Tilly (1998) sebagai new social movements, yaitu gerakan-gerakan yang berbasis pada isu-isu seperti lingkungan, preferensi seksual, dan gender. Gerakan-gerakan tersebut tidak semata-mata menjadikan negara sebagai target, sehingga hadirlah berbagai definisi baru mengenai gerakan sosial. Salah satunya, Snow (2004) yang mengatakan:

\footnotetext{
"....social movements can be thought of as collectivities acting with some degree of organization and continuity outside of institutional or organizational channels for the pure of challenging or defending extant authority, whether it is institutionally or culturally based, in the group, organization, society, culture, or world order of which they are apart".
}

Dari pernyataan itu, Snow mendefinisikan gerakan sosial sebagai gerakan kolektif yang terorganisasi dan berkelanjutan, yang bertujuan untuk menentang otoritas yang ada, baik secara institusi maupun kultural. Penjelasan Snow menunjukkan bahwa negara bukanlah satu-satunya source of power and authority. Gerakan sosial tidak hanya lain dari berbagai insititusi dan cultural meaning yang menjadi bagian dari masyarakat. Para ahli memahami bahwa gerakan sosial merupakan gejala yang begitu kompleks. Pemahaman ini mengantarkan pentingnya pembahasan yang bersifat komprehensif dan integral antara political opportunity structure, resources mobilization theory, dan collective action frames (McAdam et al. 1997). Ketiga hal tersebut merupakan faktor dari muncul dan berkembangnya suatu gerakan sosial.

Political Opportunity Structure (Struktur Kesempatan Politik), merupakan sebuah konsep yang menyatakan bahwa kondisi struktur politik dalam hal tertentu memiliki pengaruh yang cukup signifikan terhadap perkembangan suatu gerakan sosial. Jadi, suatu gerakan sosial tergantung pada keadaan Struktur Kesempatan Politik (SKP) itu sendiri. Dalam hal ini, SKP menjadi ruang multidimensi yang gerakan sosial dan tindakannya bisa saja dimudahkan (facilitated) atau bisa saja direpresi (dihambat), sehingga tak bisa berkembang (repressed) (Oliver \& Myers 1998).

Secara umum, hambatan atau kesempatan politik bagi suatu gerakan sosial dapat dipilah ke dalam dua kategori: pola hubungan tertutup dan pola hubungan terbuka. Pola tertutup menciptakan hambatan bagi gerakan sosial, sedangkan pola terbuka membuka kesempatan bagi munculnya gerakan akibat dari politik yang lebih kompetitif antara elite, antara partai politik, dan juga antara kelompok kepentingan. Semakin terbuka iklim politik, semakin memberikan kesempatan untuk muncul dan berkembangnya gerakan sosial dan sebaliknya, semakin tertutup iklim politik, semakin tertutup kesempatan muncul dan berkembangnya suatu gerakan sosial (Muhtadi 2011).

McAdam \& Snow (1997) menjelaskan bahwa SKP adalah pola hubungan antara elite politik, antara partai politik, antara kepentingan dan semua ini dengan masyarakat sebagai konstituen. Kemudian dia menghimpun empat dimensi struktur politik, yaitu (1) keterbukaan dan ketertutupan relatif sistem politik; (2) stabilitas atau instabilitas jejaring keterikatan elite; (3) adanya atau tiadanya aliansi-aliansi elite (4) kapasitas dan kecenderungan negara untuk melakukan represi (McAdam \& Snow 1997).

Resource Mobilization Theory (Teori Mobilisasi Sumber Daya), setiap gerakan sosial tentunya membutuhkan sumber daya untuk bisa menjalankan aktivitas kolektifnya. Dalam hal ini, gerakan sosial memiliki beberapa tugas penting, seperti memobilisasi pendukung, mengorganisasi sumber 
daya, yang dalam level yang lebih jauh berdampak pada munculnya simpati elite-elite dan masyarakat secara umum terhadap cita-cita gerakan. Inilah konsep yang disebut resources mobilization (Opp 2009). Konsep ini secara mendasar berusaha mengetahui bagaimana sebuah kelompok mengupayakan resources yang mereka miliki untuk bisa melakukan perubahan sosial dan tercapainya tujuan kelompok (Edwards dan McCarthy 2004). Konsep ini berusaha melihat dorongan upaya, baik secara kolektif maupun individual, yang muncul sebagai bagian dari pencapaian tujuan yang dimiliki oleh gerakan sosial.

Resources sendiri sebenarnya memiliki makna yang begitu luas. Resources dapat terdiri dari kekuatan finansial, akses terhadap media, dukungan simpatisan, loyalitas grup. Ia juga bisa terdiri dari kepemilikan ruang/gedung, pengetahuan (stock of knowledge), dan skill (keahlian) yang dimiliki oleh aktor (Opp 2009), termasuk di dalamnya ideologi dan nilai gerakan. McCarthy (1996) menjelaskan dua kategori dalam dalam membangun struktur mobilisasi, yaitu struktur formal dan struktur informal. Dalam struktur mobilisasi informal yang identik dengan gerakan lokal, jaringan kekerabatan, dan persaudaraan menjadi dasar bagi rekruitmen gerakan.

Collective Action Frames (pembingkaian aksi kolektif), pada teori gerakan sosial memperkenalkan perspektif pembingkaian aksi kolektif untuk menjalankan transformasi mobilisasi sosial ke dalam mobilisasi aktual dalam upaya meyakinkan kelompok sasaran yang beragama dan luas sehingga mereka terdorong untuk melakukan aktivitas perubahan, Klandermans dalam Muhtadi, menjelaskan mobilisasi aksi berhubungan dengan persoalan psikologi sosial klasik mengenai hubungan antara sikap dan perilaku (Muhtadi 2011).

Perspektif pembingkaian aksi kolektif dapat dijelaskan sebagai konstruksi budaya sebagai sistem kesadaran kolektif yang mengandung makna-makna yang menjadi kekuatan legitimasi dan motivasi lahirnya tindakan-tindakan kolektif. Pada kondisi struktural yang kondusif tidaklah cukup bagi perkembangan suatu gerakan sosial. Gerakan sosial juga memerlukan apa yang disebut sebagai bagian dari pengemasan ideologi untuk dapat diterima berbagai pihak.

Inilah yang disebut collective action frames yang merupakan bagian dari sebuah proses framing dalam gerakan sosial, yakni semacam skema interpretasi yang merupakan sekumpulan beliefs and meanings dan berorientasi pada aksi yang menginspirasi dan melegitimasi aktivitas sebuah organisasi gerakan sosial. Dalam hal ini, kerangka (frame) dibangun untuk memberikan makna dan menginterpretasi kejadian atau kondisi tertentu, yang dimaksudkan untuk memobilisasi potensi pengikut, serta untuk mendapatkan dukungan berbagai pihak (Benford \& Snow 2000).

Berkaitan dengan proses framing, Benford dan Snow menyebutkan tiga hal yang menjadi perhatian utama, yang disebut core framing tasks. Pertama adalah diacnostic framing, yaitu yang dikonstruksikan dalam sebuah gerakan sosial guna memberikan pemahaman mengenai situasi dan kondisi yang sifatnya problematik. Kondisi mengenai apa atau siapa yang disalahkan, sehingga membutuhkan adanya suatu perubahan (Benford \& Snow 2000).

Dalam level ini, aktor-aktor gerakan sosial mendefinisikan permasalahan-permasalahan apa saja yang menjadi isu utama yang membuat mereka menginginkan adanya perubahan. Kedua, prognostic framing, yaitu artikulasi solusi yang ditawarkan bagi persoalan-persoalan yang sudah diidentifikasikan sebelumnya. Dalam aktivitas prognostic framing ini gerakan sosial juga melakukan berbagai penyangkalan atau menjamin kemanjuran dari solusi- solusi yang ditawarkan (Benford \& Snow 2000). Terakhir adalah motivational framing, yaitu elaborasi panggilan untuk bergerak atau dasar untuk terlibat dalam usaha memperbaiki keadaan melalui tindakan kolektif (Benford \& Snow 2000).

\section{Kesempatan politik pasca reformasi}

Pada masa kepemimpinan orde baru, yang dipimpin oleh Soeharto dikenal dengan kebijakan asimilasi bagi warga etnis Tionghoa yang dikategorikan warga non pribumi. Kebijakan asimilasi menyeluruh baru diterapkan selama pemerintahan Soeharto yang otoriter (1966-1998). Soeharto sendiri menyatakan secara jelas bahwa warga negara Indonesia keturunan Cina harus segera berintegrasi dan berasimilasi dengan masyarakat Indonesia asli. Namun, dalam praktik seringkali asimilasi 
berjalan dengan kabur dan bertentangan dan bahkan dalam beberapa kebijakan Soeharto cenderung anti asimilasi karena pertimbangan kondisi politis. Sebagai contoh, toleransi terhadap agama-agama minoritas dan pembedaan antara pribumi dan non-pribumi cenderung malahan memilah, dan bukan mempersatukan etnik Tionghoa dan orang Indonesia asli. Dengan perkataan lain, etnik Tionghoa tetap terpisah dari komunitas tuan rumah.

Kebijakan asimilasi Soeharto membawa hasil yang bermacam-macam. Pada satu sisi, kebijakan tersebut membuat etnik Tionghoa secara kebudayaan kurang Tionghoa karena mereka kehilangan penguasaan atas bahasa Tionghoa dan menjadi lebih berurat-berakar dalam kebudayaan nasional Indonesia. Di sisi lain, sebagian besar dari mereka tetap mempertahankan identitas terpisah karena rezim Soeharto menawarkan kesempatan untuk melestarikan identitas etnik Tionghoa di bawah ideologi negara Pancasila. Ideologi negara yang menjamin kebebasan beragama, memberikan kesempatan kepada etnik Tionghoa di Indonesia untuk bersembunyi di balik identitas agama minoritas seperti agama Budha, Tridharma dan Konfusianisme.

Agama-agama ini merupakan agama-agama Tionghoa dan memiliki pengikut Tionghoa dalam jumlah yang sangat besar. Identitas etnik Tionghoa dipertahankan melalui agama-agama. Selain itu, rezim menerapkan kebijakan-kebijakan yang menyebabkan keterpisahan etnis/ras secara terus-menerus dengan penerapan dikotomi pribumi dan nonpribumi. Selanjutnya, rezim Soeharto membatasi ruang gerak orang Tionghoa ke sektor ekonomi. Dengan demikian hal ini secara tidak sengaja menambah kekuatan ekonomi mereka dan secara bersamaan pula memisahkan penduduk keturunan Tionghoa dari massa penduduk asli yang kebanyakan dari mereka berekonomi lemah (Suryadinata 2003).

Pasca runtuhnya rezim orde baru, keadaan politik di Indonesia yang melahirkan reformasi membawa keterbukaan pada struktur dan sistem politik yang ada. Reformasi digambarkan sebagai ruang yang segala aktivitas politik dijamin kebebasannya. Pembentukan partai, serikat pekerja, organisasi massa, semua dijamin kebebasannya pada masa reformasi. Jaminan tersebut adalah bagian dari usaha untuk menciptakan struktur dan sistem politik yang terbuka. Pada masa reformasi, seperti telah disebutkan sebelumnya, terbangun sistem politik yang terbuka (open system).

Hal ini berbeda dengan era orde baru, pemerintah kala itu sangat represif demi menjaga kestabilan politik untuk mendukung stabilitas ekonomi. Para era ini setiap warga negera diberikan akses untuk bebas mengekspresikan dirinya untuk berkumpul, berpendapat, melakukan demonstrasi, mengkritik pemerintah, tanpa harus takut dengan tindakan represif pemerintah. Kesempatan politik ini juga dimanfaatkan oleh para relawan Budha Tzu Chi di Indonesia yang terus mengembangkan misi organisasinya dengan merekrut para relawan yang umumnya berasal dari etnis Tionghoa. Berdasarkan informasi resmi, sejarah masuknya Tzu Chi di Indonesia dimulai pada tahun 1993 dan secara perlahan melakukan kegiatan sosial kemanusiaan meskipun masih ada ancaman diskriminasi oleh masyarakat pribumi atau dengan kata lain masih melakukan aktivitas sosialnya dengan melihat situasi dan kondisi.

Di Kota Medan, Tzu Chi mulai didirikan pada tanggal 28 Agustus 2003 dengan statusnya sebagai kantor cabang Medan. Penanggung jawab pengobatan dan bakti sosial Tzu Chi Kota Medan, Alice Wijaya, (64 tahun), mengatakan pada saat itu, mulai didirikannya yayasan Budha Tzu Chi karena ada relawan dari Jakarta yang ingin mengembangkan Tzu Chi di Kota Medan dengan merekrut dan melatih para relawan, Alice Wijaya adalah salah satu relawan pertama sekali dilatih di Kota Medan. Menurutnya, pada saat awal-awal berdirinya Tzu Chi, masih ada terjadi penolakan dari masyarakat karena dianggap organsiasi Tzu Chi punya kepentingan tertentu, karena harus diakui bahwa mayoritas relawan Tzu Chi pada saat itu beretnis Tionghoa.

Budha Tzu Chi sendiri, tidak ingin disebut sebegai organisasi keagamaan, karena organisasi keagamaan kerab diidentikkan dengan organsiasi yang memiliki misi-misi keagamaan tertentu. Alice mengatakan, pada fase-fase berdirinya Tzu Chi di Kota Medan, masyarakat menilai selain ada semacam gerakan etnis Tionghoa ingin bangkit kembali, juga ada misi untuk menyebarkan ajaran 
agama Budha, atau istilahnya "Budhaisasi". Hal ini jelas dibantah, karena pada awal terbentuknya Tzuchi di Taiwan, Pendiri Tzu Chi, Master Chen Yen mengatakan, bahwa organsiasi Tzu Chi bukanlah organsiasi yang membawa misi keagamaan, melainkan misi kemanusiaan, maka dari struktur kepengurusan dan juga para relawan siapa saja bisa bergabung tanpa membedakan agama, ras, bangsa dan golongan begitu juga dengan orang yang hendak ditolong atau dibantu.

Ketua Budha Tzu Chi Kota Medan, Mujianto (64 Tahun) mengatakan, membandingkan persoalan situasi politik pada saat awal berdirinya Tzu Chi di Kota Medan dengan pada saat ini relatif lebih baik, penerimaan masyarakat akan kehadiran Tzu Chi di Kota Medan juga kian baik hal ini bisa dilihat dengan banyaknya laporan masyarakat yang ingin dibantu kesehatannya yang sakit oleh Tzu Chi. Dalam sisi yang berbeda stereotipe etnis tionghoa yang identikkan dengan etnis yang memiliki modal dan penguasaan pasar ekonomi yang kuat, juga punya kekhawatiran muncul kembali gerakan anti Tionghoa yang salah satunya pada saat peristiwa 1998 yang menyebabkan etnis Tionghoa mengalami diskriminasi dari suku yang lain, oleh sebab itu, proses perenungan Master Cheng Yen, dengan prinsip hidup bermasyarakat harus bersikap welas asih dengan berdonasi, tidak menumpukkan harta hanya untuk kepentingan pribadi namun adanya pemerataan, namun saling tolong menolong, membantu orang lain yang sedang kesusahan akan membawa kebaikan bagi orang lain dan juga diri sendiri, itu semua dilakukan melalui yayasan Budha Tzu Chi. Dalam politik identitas, Tzu Chi menjadi media untuk berbaurnya kelompok etnis Tionghoa dengan kelompok-kelompok masyarakat lainnya guna menciptakan kolektivitas dan stabilitas sosial.

Budha Tzu Chi sendiri juga memiliki aturan yang ketat mengenai politik yang berkembang di Indonesia, di antaranya jika ingin menjadi relawan di Tzu Chi tidak dibenarkan rangkap jabatan sebagai keanggotaan partai politik, bahkan relawan juga dilarang untuk melakukan aksi demonstrasi turun ke jalan. Mujianto (64 Tahun) menyebutkan:

\footnotetext{
"Relawan memang tidak boleh masuk keanggotaan partai politik, demontrasi, merokok, bahkan dalam situasi misalnya menjelang pemilihan kepala daerah, legislatif seperti itu, kegiatan Tzu Chi kita pending dahulu, karena kita gak ingin aktivitas Tzu Chi image-nya karena momentum politis, kalau masa-masa politis itu sudah selesai baru kita lanjutkan kembali”.
}

Situasi politik saat ini yang terbuka juga memberikan manfaat bagi Tzu Chi sendiri, hal ini dapat dilihat Tzu Chi di Kota Medan turut serta menjalin kerja sama (MoU) antara lain dengan pemerintah Propinsi Sumatera Utara, pemerintah Kota Medan, kepolisian, TNI dan lembaga lainnya dalam melakukan kegiatan-kegiatan antara lain bakti sosial, donor darah, pengobatan gratis, penanggulangan penyakit, dan lain sebagainya. Dengan kata lain, secara kelembagaan Tzu Chi bersama-sama dengan pemerintah untuk membantu masyarakat dalam misi kemanusiaannya. Kesempatan politik yang sangat terbuka saat ini pasca reformasi, mendukung setiap pihak baik itu masyarakat yang mengatasnamakan organisasi sosial maupun keagamaan untuk membuka kesempatannya dalam menyusun perubahan sosial. Kesempatan seperti ini juga dimanfaatkan oleh pemerintah (negara) maupun kelompok lain untuk mendukung perubahan di masyarakat.

\section{Mobilisasi sumber daya}

Kita ketahui bahwa uang adalah sumber daya paling penting bagi sebuah gerakan. Seberapa besar pun sumber daya lain yang dimiliki, aktivitas gerakan tak akan bisa berjalan kalau tidak ada yang membiayai (Edwards \& McCarthy 2004). Dalam menjalankan aksinya, setiap gerakan hampir dapat dipastikan memerlukan biaya. Karenanya, masing-masing gerakan berupaya semaksimal mungkin mencari cara untuk mengakses sumber-sumber dana. Mereka melihat bahwa sebagian gerakan mengakses dan melakukan redistribusi sumber daya dengan mendirikan yayasan (foundation). Hal tersebut selain untuk mendapatkan legitimasi, dalam tingkat tertentu juga dijadikan wahana untuk menyelenggarakan aktivitas gerakan, termasuk pendanaan. McCarthy \& Zald (1977) berpendapat bahwa sebuah sistem politik yang terlembaga merangsang terbentuknya prospek membangun aksi-aksi kolektif dan pilihan bentuk gerakan. Mereka mendefinisikan struktur mobilisasi sebagai 
kendaraan kolektif baik formal dan juga informal. Melalui kendaraan ini, masyarakat memobilisasi dan berbaur dalam aksi bersama. Konsep ini berkonsentrasi kepada jaringan informal, organisasi gerakan sosial dan kelompok-kelompok di tingkatan meso (Situmorang 2007).

Kepala Sekretariat Tzu Chi Kota Medan, Steven Halim, (24 tahun) menyebutkan sumber utama pendanaan Tzu Chi berasal dari donatur yang saat ini berjumlah kurang lebih 18 ribu donatur. Donasi yang diberikan oleh para donatur jumlahnya cukup bervariasi, berdasarkan pengalaman Steven, donasi tertinggi berjumlah 100 juta rupiah, sementara yang paling kecil berjumlah Rp1.000-Rp 2.000. Para donatur tetap secara sadar akan memberikan donasinya tiap bulan apakah dengan langsung melalui transfer ke rekening Tzu Chi atau dengan meminta para relawan Tzu Chi untuk langsung menjemput donasinya ke rumah masing-masing. Tzu Chi sendiri tidak mematok berapa donasi yang harus diberikan, namun nasehat Master Chen Yen menganjurkan untuk hidup saling berbagi dengan mengajarkan manusia untuk lebih baik berbagi dari pada menerima, bahkan pada setiap kantor atau individu disediakan "celengan bambu".

"Melihat sejarah , gerakan kemanusiaan Tzu Chi itu juga dimulai dari celengan bambu, dimana Master mengajak para ibu rumah tangga di Taiwan untuk menyisihkan 50 Sen uang belanja untuk disumbangkan ke orang miskin, kami juga melakukan hal yang serupa, menyiapkan celengan untuk saya masukkan uang, apakah itu uang kertas atau logam. Bisa saja misalnya, saya masukkan uangnya persatu bulan, namun Master mengajarkan agar kita berdonasi setiap hari walaupun cuma 500 rupiah, agar untuk melatih diri kita setiap hari untuk punya sikap welas asih". Ste. (24 tahun).

Donasi yang dikumpulkan oleh relawan Tzu Chi dibagi menjadi dua jenis, pertama, donasi yang diperuntukkan dana amal, dan donasi yang kedua diperuntukkan dana administrasi operasional. Dana amal digunakan untuk kegiatan amal saja, sedangkan dana administrasi operasional digunakan untuk membayar operasional kantor seperti tagihan listrik, internet, telepon dan membayar gaji karyawan. Para donatur dipersilahkan untuk memilih donasinya digunakan untuk dana amal atau untuk dana operasional. Dana operasional tidak boleh diambil untuk dana amal begitu juga sebaliknya.

Dalam satu bulan, Tzu Chi Cabang Medan dapat mengumpulkan donasi uang sekitar 600-700 juta rupiah. Dalam berdonasi diwajibkan untuk menyebutkan namanya, dan menghindari donasi tidak mau menyebutkan nama (No Name), hal ini dimaksudkan untuk transparansi donasi yang masuk agar dapat dilaporkan kepada yayasan. Setiap donatur yang sudah berdonasi akan diberikan kwitansi resminya pada bulan berikutnya. Sementara untuk dana operasional, setiap bulannya mendapatkan donasi sekitar 60-70 juta rupiah. Selain memberikan donasi berbentuk uang, ada juga relawan yang mendonasikan tanah dan bangunannya untuk dijadikan kantor, seperti kantor Tzu Chi di Komplek Cemara Asri dan di Jati Junction merupakan donasi dari relawan. Ketua Tzu Chi International Medical Association (TIMA) Irwanto Phen (62 tahun) mengatakan, hal yang menarik dari organisasi Tzu Chi dibandingkan dengan organisasi kemasyarakatan lainnya adalah setiap pengurus yayasan adalah relawan dan semua turut andil untuk bekerja sesuai dengan bidang bidangnya.

\footnotetext{
"Saya senangnya di Tzu Chi ini, kan banyak bos-bos pengusaha, mereka gak hanya nyumbang duit, tapi mau juga nyumbang tenaga jadi relawan aktif, apalagi disini kita para relawan kalau ada pertemuan-pertemuan Tzu Chi di Jakarta atau di Taiwan mengeluarkan duit sendiri, ada bakti sosial misalnya di Nias, ya tiket, penginapan dan ongkos kesana gunakan uang sendiri”.
}

Menurutnya, sistem pengorganisasian dan manajemen dalam menghimpun sumber daya para relawan seperti ini yang baik dan belum ditemukan di organsiasi sosial kemasyarakatan lainnya. Begitu juga dengan dana-dana sosial yang dikucurkan untuk masyarakat yang ingin dibantu semua ada proses pertanggungjawabannya. Dalam menghimpun para relawan, Tzu Chi yang mayoritas keanggotaannya beretnis Tionghoa dan beragama Budha, juga memanfaatkan jaringan dan relasi keluarga, kerabat hingga rekan bisnis untuk mengajak masuk dan terlibat menjadi seorang relawan dan menjadi donatur tetap. Maka tidak heran jaringan etnis Tionghoa menjadi sumber solidaritas untuk memfasilitasi gerakan misi kemanusiaan Tzu Chi ini. 


\section{Membangun framing gerakan kemanusiaan}

Tzu Chi sebagai sebuah gerakan sosial kemasyarakatan memiliki framing dalam pengemasan ideologinya. Framing juga sekaligus menjadi penanda bagi aktivitas-aktivitas para aktor relawan gerakan Tzu Chi di Kota Medan. Menurut Benford \& Snow (2000) dua komponen penting dalam memframing gerakan, yaitu, diagnosis elemen atau mendefinisikan masalah dan sumbernya dan prediksi elemen sekaligus mengidentifikasi strategi yang tepat untuk memperjuangkan masalah tersebut. McCarthy \& Zald (1977) memperjelas apa yang dimaksud Snow dan Benford tersebut dengan mengidentifikasi topik-topik penting yang tidak hanya berhubungan dengan proses framing tetapi juga memainkan peranan penting dalam membentuk framing. Topik pertama adalah kontradiksi budaya dan alur sejarah. Dia berpendapat bahwa kesempatan politik dan mobilisasi, sering kali tercipta melalui ketegangan budaya dan kontradiksi yang telah berlangsung lama muncul menjadi bahan proses framing, seperti keluhan dan ketidakadilan, sehingga aksi kolektif menjadi mungkin.

Kontradiksi budaya juga menjadi penyebab mobilisasi ketika dua atau lebih tema-tema budaya yang memiliki potensi kontradiksi dibawa ke dalam kontradiksi aktif melalui kekuatan aksi kolektif. Kemungkinan lain, misalnya, ketika realitas perilaku sekelompok masyarakat dilihat secara substansi memiliki perbedaan dari justifikasi ideologi sebuah gerakan sosial.

Topik kedua proses framing sebagai sebuah aktivitas strategi. Keretakan dan kontradiksi budaya menyediakan konteks dan sekaligus kesempatan bagi kader-kader gerakan, yaitu, pemimpin, partisipan inti, aktivis dan simpatisan. Akan tetapi, ada sebuah proses aktif framing dan pendefinisian ideologi, simbol, peristiwa-peristiwa yang mampu menjadi ikon oleh para pengusaha moral. Para pengusaha moral ini bisa dari kalangan aktivis maupun dari kalangan di luar aktivis. Kalangan wartawan, masyarakat, asosiasi pemimpin, politisi, dan penulis juga berkontribusi menentukan pilihan framing strategi dalam gerakan sosial (Situmorang 2007).

Dalam hal diagnostic Framing, gerakan sosial yang dibangun oleh Tzu Chi adalah kehidupan umat beragama yang semakin kian individualistik, materialistik dan semakin terkikisnya nilai-nilai kemanusiaan. Nilai nilai yang terideologi bersumber dari ajaran-ajaran Budha yang diterjemahkan oleh kata-kata perenungan (Jing Si Aphorisms) oleh Master Cheng Yen sendiri. Master Cheng Yen sebagai orang yang mendirikan Tzu Chi digambarkan sebagai seseorang yang menjadi panutan masyarakat, sosok yang sederhana, mandiri, teladan cinta kasih dan bersikap welas asih. Sikap yang dimiliki oleh Master tidak terbentuk dengan sendirinya, karena jika melihat sejarah, proses perenungan terbesar Master Cheng Yen ialah saat beliau bersama para pengikutnya mengunjungi umat yang menjalani pendaharan lambung di suatu balai pengobatan, saat itu dia melihat banyak bercak darah di lantai namun tidak tampak melihat pasien, namun pada akhirnya diketahui bahwa bercak darah itu berasal dari perempuan yang mengalami keguguran dan terpaksa pulang karena tidak memiliki uang untuk berobat.

Setelah itu, karena jalinan jodoh juga, Master Cheng Yen bertemu dengan tiga orang suster Khatolik dan mempertanyakan kepada Master, bahwa agama Khatolik telah membangun rumah sakit, sekolah dan panti jompo sementara agama Budha apa? Proses tersebut menyentuh hati master karena selama ini agama Budha hanya menjalani ritualitas ajaran-ajaran Budha saja, tidak termanisfestasi dalam kehidupan sosial kemanusiaan. Master Cheng Yen sendiri mengajak pengikutnya beserta para relawan untuk memahami ajaran-ajaran Budha sesungguhnya untuk menegakkan teladan Bodhasattva dunia.

Diagnostic Framing Tzu Chi sendiri adalah ajaran-ajaran Budha universal yang dapat diterima oleh semua masyarakat, diinisiasi oleh perenungan Master Cheng Yen dan dimanifestasikan dalam misi sosial kemanusiaan tanpa membedakan bangsa, suku dan agama. Dari proses sejarah berdirinya Tzu Chi pada tahun 1996 di Taiwan akhirnya juga turut mengilhami Master melakukan gerakan kemanusiaan yang dimulai dengan membuat celengan bambu dan merajut sepatu bayi yang donasinya dipergunakan untuk bantuan kaum fakir miskin. Misi Master Cheng Yen ini mendapatkan simpati banyak masyarakat dan akhirnya bergabung menjadi relawan. Kegiatan-kegiatan kemanusiaannya 
pun kian berkembang melalui program-program yang terukur, ini juga lah yang menjadi Prognostic framing yakni solusi atas kondisi dan masalah yang ada.

Setelah melalui tahap diagnostic dan prognostic, proses framing juga melibatkan tahap yang disebut sebagai motivational framing. Ia adalah suatu elaborasi panggilan untuk bergerak yang menjadi dasar untuk terlibat dalam usaha memperbaiki keadaan melalui tindakan kolektif. Tahap ini merupakan tangga menuju tercapainya sebuah cita-cita gerakan. Aktivitas ini adalah aksi yang melampaui diagnosis dan prognosis sebelumnya. Tzu Chi merekrut relawan atas dasar sukarela, motivasinya adalah misi kemanusiaan untuk menolong sesama, selain itu Tzu Chi merupakan organisasi yang terbuka kepada siapa saja yang ingin bergabung. Salah seorang relawan yang beragama Kristen, Yul. (30 tahun) motivasinya untuk bergabung adalah Tzu Chi meengajaknya untuk berbuat cinta kasih tidak hanya untuk beragama Budha namun semua agama.

\begin{abstract}
"Saya melihat ajaran Master Cheng Yen itu universal, mereka mau membangun bersamasama gotong royong untuk membanun rumah ibadah non Budha, saya menjadi relawan sejak 2013, dan tidak ada sama sekali niat saya untuk pindah agama Budha, saya tetap beribadah ke gereja. Sebenarnya ada kesamaan ajaran kristen dengan Budha itu sendiri. Di Tzu Chi tidak ada diskriminasi antara Budha dengan yang non Budha, meskipun mayoritas Budha".
\end{abstract}

Framing gerakan Tzu Chi juga dikemas melalui stasiun TV milik Tzu Chi, yakni DAAI TV dimana program-program yang edukatif dan inspiratif, menggugah kesadaran batin untuk mensyukuri dan memaknai kehidupan, mengetuk hati masyarakat untuk memiliki semangat kerelawanan dalam membantu sesama, dan peduli pada pelestarian lingkungan. Aneka program unggulan DAAI TV saat ini dikategorikan dalam 8 topik: drama, anak, budaya humanis, berita terkini, lingkungan, kesehatan, keluarga, serta motivasi \& spiritual saat DAAI TV cuma ada di Taiwan dan Indonesia saja. DAAI TV dirancang sebagai stasiun tv swasta yang non komersil melainkan TV sosial, artinya DAAI TV hingga saat ini tidak ada menerima iklan yang sifatnya mencari keuntungan, yang ada hanya iklan layanan masyarakat.

\title{
Gerakan purifikasi dan modernisasi ajaran Budha
}

Dengan beragamnya aliran dan sekte dalam Budha itu sendiri misalnya aliran besar dalam Agama Budha (Mahayana dan Hinayana), maka yang menjadi pertanyaan, Budha Tzu Chi yang didirikan oleh Master Chen Yen masuk dalam aliran yang manakah? Kepala Sekretariat Tzu Chi Medan, Stevan (24 Tahun) mengatakan, Tzu Chi sebenarnya tidak masuk dalam aliran Mahayana maupun Hinayana. Karena ajaran Master Chen Yen merupakan ajaran Budha yang sesungguhnya, bahkan ajaran Tzu Chi ini juga bukanlah suatu aliran baru dalam ajaran Budha itu sendiri. Namun, jika dilihat dari aktivitas ritual ibadahnya, banyak bagi pengikut aliran-aliran Budha mengidentifikasikan bahwa Tzu Chi masuk dalam aliran Mahayana, namun selalu disampaikan bahwa Tzu Chi merupakan Ekayana, yakni tidak membawa aliran tertentu. Sejauh ini juga hubungan Tzu Chi dengan aliran-aliran Budha yang lain sangat baik, karena pada dasarnya inti ajaran Budha sama dengan yang lainnya. Para pengikut Tzu Chi juga diperbolehkan untuk datang ke vihara Budha mana saja untuk melakukan praktik ibadah, meskipun Tzu Chi sendiri tidak memiliki vihara, yang ada hanyalah Griya Jing Si yakni berada langsung di Taiwan tepatnya di kediaman Master Chen Yen sendiri.

Dalam kerangka beribadah, Tzu Chi yang pengikutnya beragama Budha mempunyai ajaran yang berbeda dengan yang umumnya dilakukan oleh orang agama Budha pada umumnya. Adapun beberapa ajaran antara lain: tidak membakar dupa, membakar kertas, memberikan sesaji bagi yang sudah meninggal karena menurut mereka itu bukanlah ajaran murni Budha melainkan budaya Tao dan pengikut konghucu. Kepala Hubungan Masyarakat (Humas) Tzu Chi, Sofyan Tjiawi (38 tahun) mengatakan bahwa Tzu Chi turut memberikan pendidikan yang rasional dalam memahami ajaranajaran Budha, terutama yang berkenaan dengan ibadah. Hal ini tidak terlepas dari ajaran-ajaran Master Chen Yen yang menekankan pentingnya ajaran Budha yang sesungguhnya. 
“di Tzu Chi memang diajarkan untuk tidak melakukan praktek praktek ritual seperti, membakar kertas atau dupa, karena itu kan menyebabkan polusi udara, selain itu juga memberikan sesembahan kepada orang yang meninggal seperti buah-buahan. Hal -hal seperti itu memang disampaikan oleh Master, namun tetap dikembalikan kepada para pengikutnya, ada yang memang masih menjalankan praktek seperi itu, namun tetap ada proses pendidikannya agar yang lain tersadarkan, tidak bisa dipaksakan.”

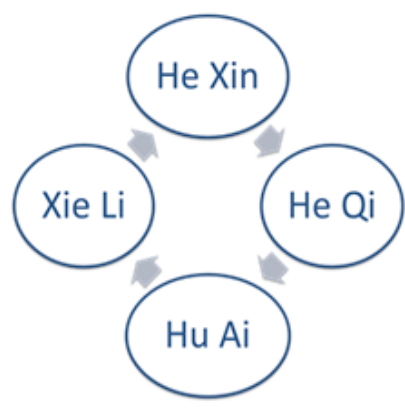

Gambar 1.

Struktur 4 in 1 Tzu Chi

Modernisasi dalam agama Budha juga dapat dilihat dari struktur dan manajemen yang diterapkan dalam Tzu Chi yang menggunakan konsep 4 in 1 dimana, struktur dan tanggung menjadi 4 kelompok peran, yakni: 1) Team He-xin berperan mewariskan ajaran Jingsi, 2) Team He-qi berperan melakukan penyampaian program, pendampingan dan pemberian perhatian, 3) Team Hu-ai berperan merencanakan kegiatan, dan 4) Team Xie-li berperan merealisasikan kegiatan bukan membagi jabatan. Adapun fungsi sistem 4 in 1 ini antara lain, meminimalisir konflik, adanya prinsip kesetaraan semua anggota, tidak mengenal atasan dan bawahan, dan membangun loyalitas semua relawan. Data yang dikumpulkan pada Oktober 2016 keanggotaan Tzu Chi berjumlah 2074 orang yang tersebar di Medan, Tebing Tinggi, Pematang Siantar, Deli Serdang, Serdang Bedagai, Binjai, langkat dan Kisaran. Jika dilihat dari keanggotaan pada basis agamanya meliputi, anggota yang beragama Budha berjumlah 1832, Islam sebanyak 140 orang, Kristen (Protestan-Katolik) sebanyak 88 orang, Hindu sebanyak 8 orang dan Konghucu sebanyak 6 orang, namun tidak semua anggota aktif melakukan kegiatan.

\section{Simpulan}

Manifestasi ajaran-ajaran Budha yang dikemas dalam organsisasi Tzu Chi menjadikan agama kian terorganisir, yang lahir sebagai akibat dari kecenderungan umum ke arah pengkhususan fungsional. Pengalaman spiritual pendiri Tzu Chi menjadikan corak organisasi kemanusiaan ini punya pengaruh secara umum melalui proses pemasyarakatan dan perubahan-perubahan dalam memahami konteks beragama. Gerakan sosial organisasi Tzu Chi difokuskan pada implementasi ajaran-ajaran Budha melalui misi kemanusiaan, sebab menurut Tzu Chi, inti ajaran Budha ialah menebar cinta kasih dan menolong sesama manusia. Ideologi ini lah yang kian berkembang dan mendapatkan tempat di hati umat yang beragama Budha. Mereka pun akhirnya masuk di Tzu Chi menjadi relawan dan donatur tetap Tzu Chi. Menariknya lagi, misi kemanusiaan ini juga mendapatkan tempat bagi mereka yang yang tidak beragama Budha, melalui kegiatan-kegiatan sosial kemanusiaan yang umumnya diberikan oleh Tzu Chi kepada masyarakat non Budhis. Organisasi Tzu Chi juga dibangun oleh atas dasar kemanusiaan tidak melihat latar belakang suku, agama dan ras, sehingga siapa saja yang ingin bergabung dalam misi kemanusiaan sangat terbuka. Akhirnya Tzu Chi membangun framing sebagai organisasi sosial multi agama, ras dan etnis dan membangun hubungan yang baik, tidak hanya kepada aliran agama Budha dan sekte-sektenya, melainkan kepada agama-agama yang lain. Tzu Chi menjadi organisasi keagamaan yang membangun sistem keorganisasiaan yang lebih modern, rasional dengan membawa misi nilai-nilai universal. Master Chen Yen yang menjadi tokoh yang 
karismatik, yang setiap perkataan dan nasehatnya hasil perenungannya selama di Taiwan menjadi sumber inspirasi bagi keanggotaan Tzu Chi dalam menjalankan rutinitas baru dalam memahami makna sebenarnya ajaran Budha dan juga menjalankan misi-misi kemanusiaannya.

\section{Daftar Pustaka}

Armstrong EA \& Bernstern M (2006) Culture, power, and institutions: A multi-institutional politics approach to social movements. Sociological Theory 26 (1):74-94.

Benford R dan Snow DA (2000) Framing Process and Social Movements: An Overview and Assesment dalam Annual Review of Sociology 26:611-39.

Edwards B \& McCarthy (2004) Resource and Mobilization. h : 116-152 dalam The Blackwell Companion to social Movement. Massachusetts: Blackwell Publishing.

Hikam AS (1996) Demokrasi dan Civil Society . Jakarta: LP3ES.

McAdam D \& Snow DA (1997) Special Movement: Reading on Their Emergence, Mobilization and Dynamic. US: Roxbury Publishing Company.

McCarthy JD (1996) Constrain and Opportunities in Adopting, Adapting, and Inventing. Dalam Comparative Perspective on Social Movement Political Opportunity, Mobilization Structure, and Cultural Framing. Cambridge: Cambridge University Press.

McCarthy JD \& Zald MN (1977) Resource mobilization and social movement: A partial theory. American Journal of Sociology 82 (6):1212-1241.

Mirsel R (2004) Teori Pergerakan Sosial. Yogyakarta: Insist.

Morris S (2000) Defening Non Frofit Sector, Some Lesson from History dalam International Journal of Voluntary and Non Profit Organization 11 (1).

Muhtadi B (2011) Demokrasi zonder toleransi: Potret Islam pasca orde baru. Makalah Diskusi 'Agama dan Sekularisme : Pengalaman di Indonesia' Komunitas Salihara. Jakarta.

Mujianto (2016) [Personal communication] 10 Desember 2016.

O’Dea TF (1996) Sosiologi Agama Suatu Pengenalan Awal. Tim Penerjemah YASOGAMA. Jakarta: PT. Raja Grafindo Persada.

Oliver PE dan Myers DJ (1998) Diffusion models of cycles of protest as a theory of social movements. Congress of the International Sosiological Association, Juli 1998, Montreal.

Opp KD (2009) Theories of Political Protest and Social Movements: a Multidiciplinary Introduction, Critique, and Synthesis. London: Routledge.

Phen I (2016) [Personal communication] 31 Mei 2016.

Porta D \& Diani M (2006) Social Movement, An Introduction (2nd edition). Victoria, Malden, Oxford: Blackwell Publishing.

Robert KA (1984) Religion in Sociological Perspective . HomeWood Illinois: The Dorsey Press.

Scharf BR (2004) Sosiologi Agama (Edisi Kedua). Jakarta: Prenada Media.

Situmorang AW (2007) Gerakan Sosial: Studi Kasus Beberapa Perlawanan. Yogyakarta: Pustaka Pelajar.

Snow D (2004) Framing Process, Ideology and Discursive Fields. Dalam: David AS, Sarah AS, \& Hanspeter K. The Blackwell Companion to Social Movements. Massachusets: Blackwell Publishing. 381-412.

Steven H (2016) [Personal communication] 22 Juli 2016.

Suryadinata L (2003) Kebijakan negara Indonesia terhadap etnik Tionghoa: Dari asimilasi ke multikulturalisme. Jurnal Antropologi Indonesia 71:1-12.

Tan SC (2008) Religion alternation, spiritual, humanism: Tzuchi Buddhist foundations in Singapore. Thesis, National University of Singapore, Singapore.

Tjiawi S (2016) [Personal communication] 2 November 2016.

Tilly C (1998) Social movements and (All Sorts of) other political interactions - local, national, and international - including identities. Theory and Society 27 (4):453-480.

Tzu Chi Indonesia (2013) Menebar Cinta Kasih di Indonesia. Jakarta: Yayasan Budha Tzu Chi.

Wijaya A (2016) [Personal communication] 11 Mei 2016. 